\title{
Pontogammarus robustoides (G.O. SARS, 1894) (Crustacea, Amphipoda), a new Ponto-Caspian invader in Great Masurian Lakes (NE Poland)
}

\author{
Anna JAŻDŻEWSKA and Krzysztof JAŻDŻEWSKI
}

Department of Invertebrate Zoology and Hydrobiology, University of Lódż, Banacha 12/16, 90-237 Eódż, Poland; Emails: jazdz@wp.pl,kryjaz@biol.uni.lodz.pl

\begin{abstract}
Recently Pontogammarus robustoides, a Ponto-Caspian amphipod species that has invaded Baltic lagoons and lower Vistula River at the end of $20^{\text {th }}$ century, abundantly appeared in some water bodies of the Great Masurian Lakes area.
\end{abstract}

Key words: Pontogammarus robustoides, Crustacea, alien species, biological invasion, Great Masurian Lakes

\section{INTRODUCTION}

A summary of amphipod acclimatization attempts and migration of these crustaceans through man-made canals putting in contact hitherto separated drainage basins in Europe, was presented already by Jażdżewski (1980). At the end of the $20^{\text {th }}$ century Central-European waters experienced particularly drastic changes in their amphipod fauna caused by very fast invasions of alien gammaroids. A group of successful invaders are four Ponto-Caspian pontogammarids (Dikerogammarus haemobaphes, D. villosus, Pontogammarus robustoides and Obesogammarus crassus) which have entered central and west European waters from the south east. All these invasions were enhanced by various human activities, especially canal constructions and intentional or unintentional (for instance with ships and barges) introductions. A review of quite recent range extensions in Europe of these gammaroids has been published by Bij de Vaate et al. (2002), Berezina (2007) and Holdich \& Pöckl (2007). The history of the still changing distribution of these amphipod invaders in Polish waters is presented by Jazdzewski \& Konopacka (2002), Konopacka (2004), Jażdżewski et al. (2005) and Grabowski et al. (2007b). All the above listed gammarid species move along the main water-courses, i.e. large rivers connected by canals (Dnieper, Pripet, Bug, Narew, Vistula, Noteć, Oder, Elbe, Rhine etc.), but also along the southern Baltic shores, although, in this case, boat or ballast water transportation is probably the main vector of range extension. Now, in large rivers, Amphipoda are represented mainly by alien species. In general, they do not enter smaller tributaries and lakes situated far from these main courses; here native amphipods are usually still present and sometimes abundant.

Great Masurian Lakes, this very special area of high natural value, are connected by small rivers Pisa and Wegorapa with larger flows of Narew and Pregel (Pregola) rivers, respectively. Until the end of the $20^{\text {th }}$ century the Masurian Lakes were inhabited only by native Gammarus lacustris G.O. Sars, 1863 and Pallaseopsis quadrispinosa (G.O. Sars, 1867) (Willer 1928, Schellenberg 1934, Micherdziński 1959, Jażdżewski \& Konopacka 1995). However, in 2001 a Ponto-Caspian invader, Dikerogammarus haemobaphes (Eichwald, 1841), has been recorded in 5 lakes of this area (Jażdżewski 2003). In August 2007, in several haphazard samples taken 
in Great Masurian Lakes, we have found one more alien amphipod, the Ponto-Caspian Pontogammarus robustoides (G.O. Sars, 1894).

\section{METHODS}

Samples were taken using a hand net in shallow waters and simply hands and knife to grasp and tear out dense alder roots of the lake's shore - just at the water line. Gammaroids were fixed in $96 \%$ ethanol for further DNA studies.

\section{RESULTS}

Gammaroids were present in 4 samples out of 6 sampling attempts (Fig. 1). The determination of animals gave the following results.

1. Talty Lake, near Talty village; 16.08 .2007 , from detritus in shallow littoral, mainly juveniles: D. haemobaphes -25 ind. (48\%), P. robustoides -27 ind. (52\%)

2. Beldany Lake, vis-a-vis Kamień village; 17.08.2007, in detritus at the shoreline, many pairs in praecopula: $P$. robustoides -60 ind. $(100 \%)$

3. Beldany Lake, near Wierzba village; 18.08 .2007 , from the roots of trees and detritus near the water line: $D$. haemobaphes -9 ind. $(21 \%)$, P. robustoides -34 ind. (79\%)

4. Talty Lake, small island at the entrance to the Modliszki Bay; 18.08.2007, in the roots of trees at the water line: G. lacustris -7 ind. (19\%), P. robustoides -29 ind. (81\%).

In all samples Pontogammarus robustoides was the dominant species.

The proportion of males, females and juveniles in the whole material differed depending on species (Table 1). Ovigerous females constituted $30 \%$ of all females in case of D. haemobaphes and $44 \%$ of $P$. robustoides, respectively. No ovigerous females were observed in G. lacustris.

\section{DISCUSSION}

Native habitats of Pontogammarus robustoides are freshwater and brackish basins of the Ponto-Caspian area: the littoral of lower river courses, estuaries, lagoons and coastal lakes (Jażdżewski 1980, Starobogatov 1995; Konopacka 2004). In the 1960s, during Soviet times, the species was successfully introduced into several dam reservoirs in Georgia, Ukraine and Lithuania, among others to the Kaunas artificial reservoir on the Neman (Nemunas) river (Lithuania) and then to the Baltic Curonian (Kuronskij) Lagoon and many lakes in Lithuania (Gasiunas 1965, Arbaciauskas 2002). In late 1980s and early 1990s P. robustoides was noted for the first time in Polish waters in Oder estuary and Szczecin Lagoon by Gruszka (1999) and in lower Vistula River and Vistula Lagoon (Konopacka 1998, Jażdżewski \& Konopacka 2000). In 1994 the species was recorded in Germany, in Peene River emptying to the Szczecin Lagoon (Rudolph 1997) indicating its possible westward penetration via brackish Baltic waters, through both human transport (boats) or natural dispersion. However, the species could have entered Vistula Lagoon and Vistula estuary also through the Pregel (Pregola) River system which connects Curonian and Vistula lagoons with a freshwater link. P. robustoides penetrated upstream the Vistula River as far as to Zegrzyński Reservoir built on the Narew River just at its mouth to the Vistula River (Grabowski et al. 2007b). Also it has been recorded recently in a rather isolated Lucieńskie Lake, situated in the Vistula valley (Grabowski \& Bącela 2005).

The present record of Pontogammarus robustoides in Great Masurian Lakes poses the question of its possible arrival route to this water system. One possibility is its upstream penetration via Narew and Pisa rivers. The possibility of this invasion corridor is high, taking into account the boat traffic between the Vistula River and Great Masurian Lakes; natural 


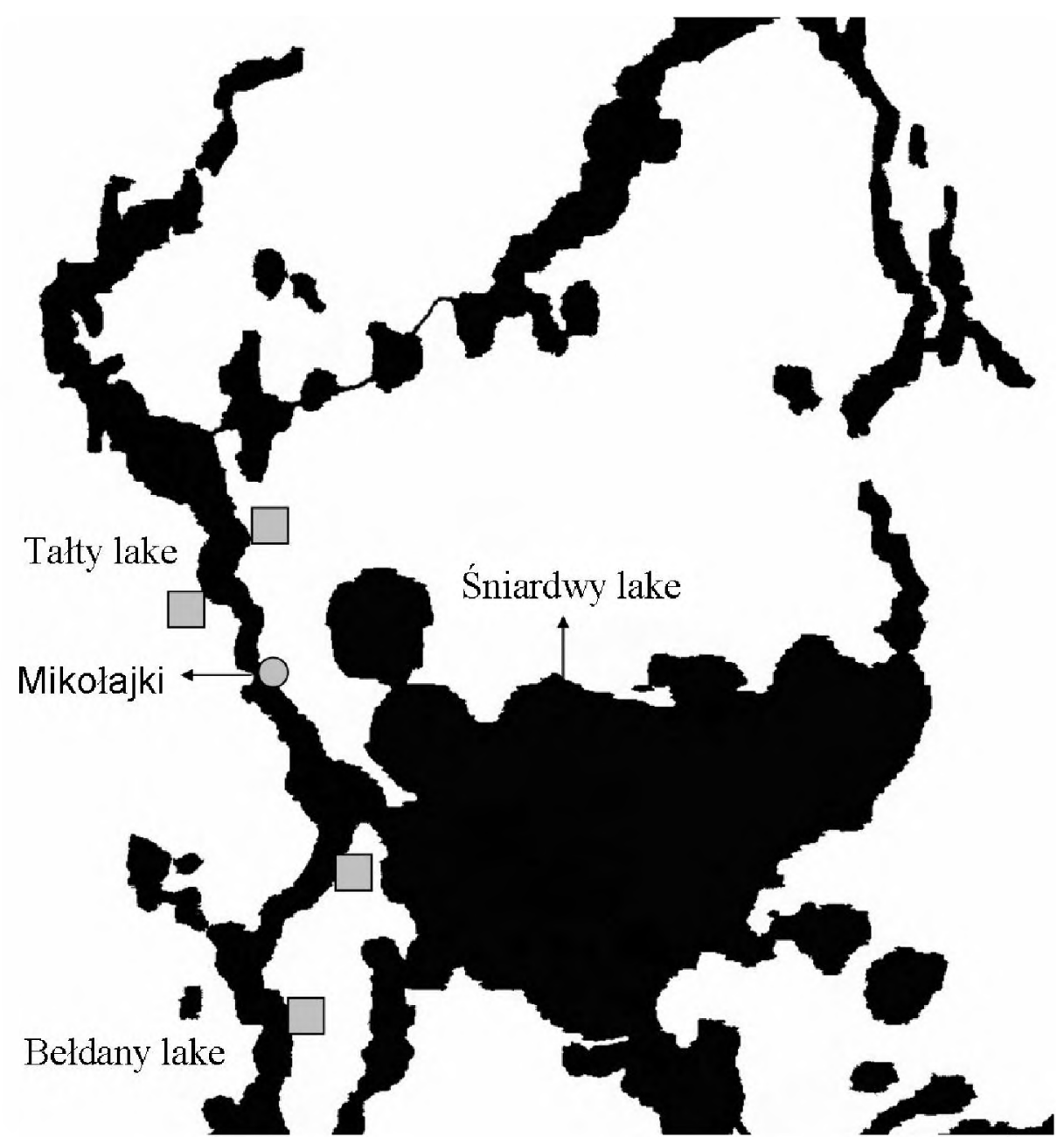

Fig. 1. Occurrence of $P$. robustoides in Great Masurian Lakes.

Table 1 . The percentage of males, females and juveniles and size ranges in every species.

\begin{tabular}{|l|c|c|c|c|c|c|c|c|}
\hline \multirow{2}{*}{ Species } & \multirow{2}{*}{$\mathrm{N}$} & \multicolumn{3}{|c|}{ Proportions \% } & \multicolumn{4}{c|}{ Size range (mm) } \\
\cline { 3 - 9 } & & $\delta$ & 0 & juv & $\delta$ & o & ovig. + & juv. \\
\hline Dikerogammarus haemobaphes & 34 & 18 & 59 & 23 & $5.5-15$ & $6.5-14$ & $11-14.5$ & $3.5-5.5$ \\
Pontogammarus robustoides & 148 & 4 & 49 & 17 & $5.5-13.5$ & $5-11.5$ & $9.5-12$ & $3.5-5.5$ \\
Gammarus lacustris & 7 & 86 & 14 & 0 & $11-11.5$ & 8.5 & - & - \\
\hline
\end{tabular}


dispersal this way is also possible. However, until June 2006 this species has not been recorded from the middle and upper Narew River nor in Pisa River (Konopacka, pers. comm.). A shorter way, but in this case for natural dispersal only, would be through the Pregel and Węgorapa rivers. Theoretically, one cannot exclude also the natural penetration of P. robustoides from the Neman (Nemunas) River (Lithuania) through the Augustowski canal, Biebrza River, Narew River and then Pisa River (Fig. 2). To solve that problem, further investigations have to be conducted. Worth of notice is the fact that P. robustoides has been successfully introduced into many water bodies in the Neman River basin, and it occurs abundantly e.g. in the Dusia Lake situated very near to the Polish-Lithuanian border (Arbaciauskas 2005, Gumuliauskaite 2007).

The population structure of collected $P$. robustoides indicates that it has been in the breeding state in August. Ovigerous females constituted over $40 \%$ of all females. The size of breeding females indicates that the second, summer generation was observed here (Bacela \& Konopacka 2005).

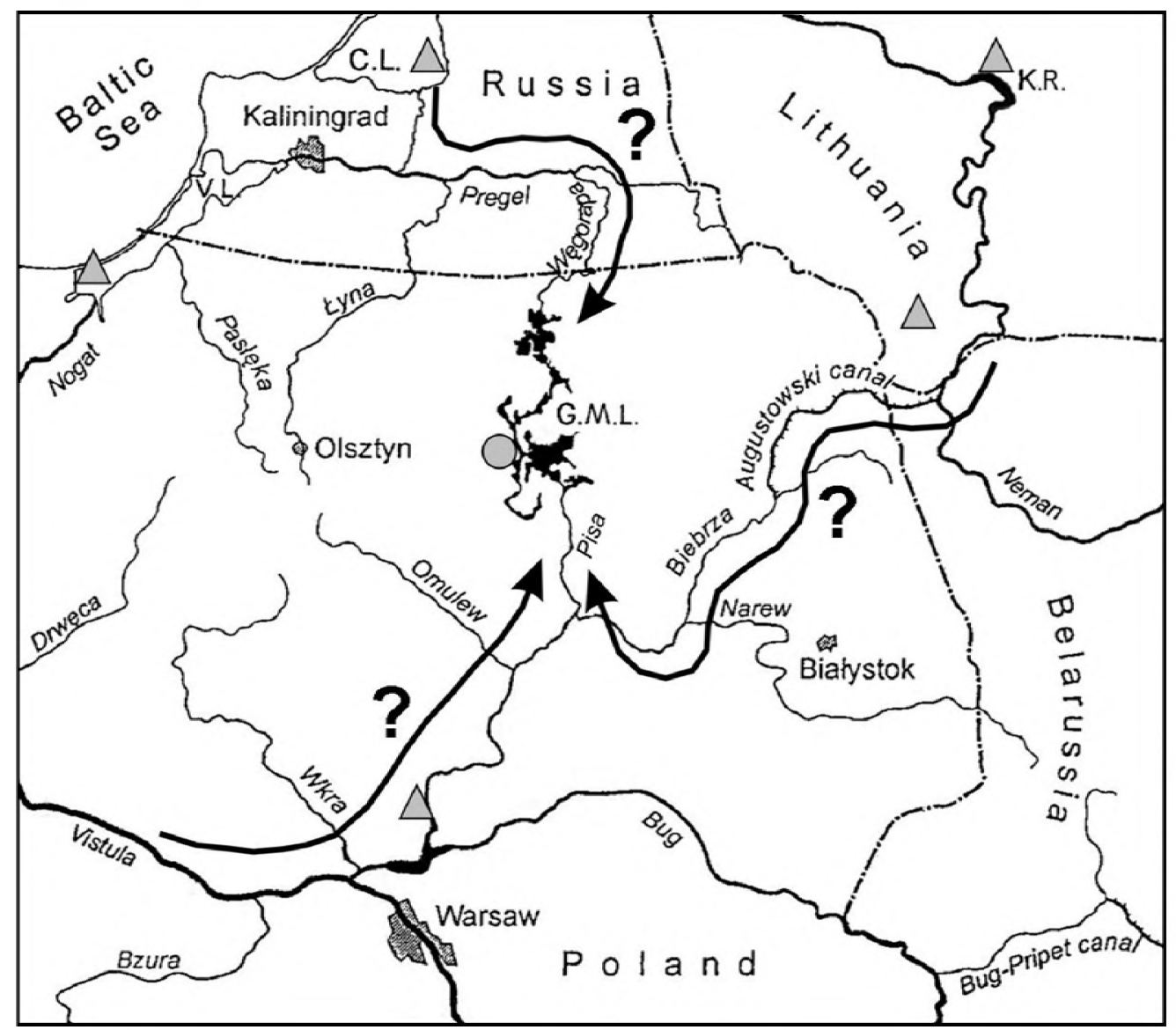

Fig. 2. Possible routes of invasion of $P$. robustoides; $\bigcirc$ - new localities, $\triangle$ - hitherto noted occurrence, K.R. - Kaunas reservoir, C.L. - Curonian Lagoon, V.L. - Vistula Lagoon, G.M.L. - Great Masurian Lakes 


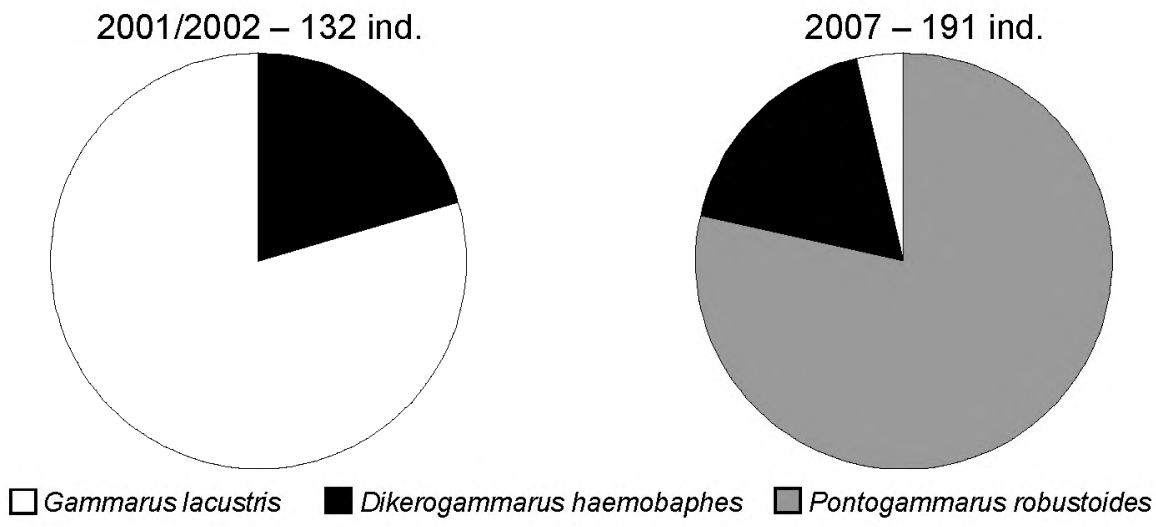

Fig. 3. Proportion of different gammarid species in collections of 2001/2002 and of 2007.

The proportion of gammaroid species found few years ago in Mazurian Lakes as well as those observed in the present study (4 samples) has been compared (Fig. 3). In the former study Gammarus lacustris was the dominant species and it was accompanied by Dikerogammarus haemobaphes. Pontogammarus robustoides was not noticed. The results of our present investigation show that the dominance in the gammaroid taxocene has been changed completely. G. lacustris is no longer the dominant species and its position is taken over by the next invasive amphipod $-P$. robustoides. Noteworthy is the comparison of the faunistic change observed by Grabowski \& Bącela (2005) in the Lucieńskie Lake in the Vistula River valley with our results presented in Fig. 3. In 2000, only G. lacustris was recorded in Lucieńskie Lake, whereas 3 years later two aliens appeared $-D$. haemobaphes and P. robustoides; they constituted approximately a quarter of the amphipod population of this lake, native G. lacustris being still the dominant amphipod.

Our results, although preliminary and based on scanty material, support the observations by Bacela \& Konopacka (2005), Grabowski et al. (2007a) and Gumuliauskaite (2007) who have stated that $P$. robustoides, producing 2-3 generations per year, has a much greater demographic potential than native $G$. lacustris. Similar observations concerning invasive potential of $P$. robustoides were published by Berezina (2007). Omnivorous feeding habits of this pontogammarid, together with its mass occurrence, may result in the decrease of the abundance both of benthic invertebrates as well as filamentous algae (Gasiunas 1975, Berezina 2007).

Taking into account the proportion of alien amphipods in our samples from Great Masurian Lakes one could say that the invasion process was successful. It seems also that the first invader, D. haemobaphes, recorded some years ago by Jażdżewski (2003), was outcompeted by the second one $-P$. robustoides. In both alien species summer breeding generation was observed indicating that the species have acclimatized well in these waters and probably they will extend their range in this area.

The present record of new invasive species in a valuable, natural area of Poland should be followed by the extensive monitoring to bring reliable empirical data for a possible management of the effects of this invasion (Strayer et. al 2007). 


\section{REFERENCES}

ARBACIAUSKAS K. 2002. Ponto-Caspian amphipods and mysids in the inland waters of Lithuania: history of introduction, current distribution and relations with native malacostracans. In: LEPPÄKOSKI E., GOLLASCH S. \& OLENTN S. (eds), Invasive Aquatic Species of Europe - Distribution, Impacts and Management, pp. 104-115. Kluwer Academic Publ., Dordrecht, IX +583 pp.

ARBACIAUSKAS K. 2005. The distribution and local dispersal of Ponto-Caspian Peracarida in Lithuanian fresh waters with notes on Pontogammarus robustoides population establishment, abundance and impact. Oceanological and Hydrobiological Studies 34 (Suppl. 1): 93-111.

BACELA K. \& KONOPACKA A. 2005. The life history of Pontogammarus robustoides, an alien amphipod species in Polish waters. Journal of Crustacean Biology 25: 190-195.

BEREZINA N.A. 2007. Invasions of alien amphipods (Amphipoda: Gammaridea) in aquatic ecosystems of NorthWestern Russia: pathways and consequences. Hydrobiologia 590: 15-29.

Bij de VaAte A., JazDzewski K., KetelaARs H., Gollasch S. \& VAN DER Velde G. 2002. Geographical patterns in range extension of macroinvertebrate Ponto-Caspian species in Europe. Canadian Journal of Fisheries and Aquatic Sciences 59: 1159-1174.

GASIUNAS I. 1965. O rezul'tatakh akklimatizacii kormovykh bespozvonochnykh Kaspijskogo kompleksa v vodemakh Litvy. Zoologicheskij Zhurnal 44: 340-343.

GASIUNAS I. 1975. Peracarida oz. Dusja (bas. Baltijskogo morja). Gidrobiologicheskij Zhurnal 11 (1): 46-50.

GRABOWSKI M. \& BACELA K. 2005. First finding of the Ponto-Caspian gammarid species Pontogammarus robustoides and Dikerogammarus haemobaphes (Crustacea, Amphipoda) in the postglacial lake of the Vistula valley. Lauterbornia 55: 107-111.

GRABOWSKI M., BACELA K. \& KONOPACKA A. 2007a. How to be an invasive gammarid (Amphipoda: Gamaroidea) comparison of life history traits. Hydrobiologia 590: 75-84

GRABOWSKI M., JAŻDŻEWSKI K. \& KONOPACKA A. 2007b. Alien Crustacea in Polish waters - Amphipoda. Aquatic Invasions 2: 25-38.

GRUSzKA P. 1999. The River Odra Estuary as a Gateway for Alien Species Immigration to the Baltic Sea Basin. Acta Hydrochimica et Hydrobiologica 27: 374-381.

GUMULIAUSKAITE S. 2007. Life history of the Ponto-Caspian amphipod Pontogammarus robustoides, and its impact on Lithuania's freshwater communities. Ph.D. dissertation, Vilnius University, Engl. summary: 3-23.

HOLDICH D. M. \& PÖCKL M. 2007. Invasive crustaceans in European inland waters. In: GHERARDI F.(ed.), Biological invaders in inland waters: Profiles, distribution, and threats, pp. 29-75. Springer, Dordrecht, Netherlands, 734 pp.

JAŻDŻEWSKI K. 1980. Range extensions of some gammaridean species in European inland waters caused by human activity. Crustaceana (Suppl. 6): 84-107.

JAŻDŻEWSKI K. 2003. An invasive Ponto-Caspian amphipod - Dikerogammanus haemobaphes (Eichwald, 1841) conquers Great Masurian Lakes, north-eastern Poland. Fragmenta Faunistica 46: 19-25.

JAŻDŻEWSKI K. \& KONOPACKA A. 1995. Pancerzowce - Malacostraca (excl. Oniscoidea). Katalog Fauny Polski (Catalogus faunae Poloniae), Warszawa, XIII, 1, $163 \mathrm{pp}$.

JAŻDŻEWSKT K. \& KONOPACKA A. 2000. Immigration history and present distribution of alien crustaceans in Polish waters. In: VON VAUPEL KLEIN J. C. \& SCHRAM F. R. (eds.), The biodiversity crisis and Crustacea. Proc. $4^{\text {th }}$ Int. Crustacean Congr., Amsterdam, 20-24 July 1998, 2, pp. 55-64. Brill, Leiden, Crustacean Issues, 12, 848 pp.

JAZDZEWSKI K. \& KONOPACKA A. 2002. Invasive Ponto-Caspian species in waters of the Vistula and Oder basins and of the southern Baltic Sea. In: LePpäKoski E., Gollasch S. \& OlEnIN S. (eds.) Invasive Aquatic Species of Europe - Distribution, Impacts and Management, pp. 384-398. Kluwer Academic Publ., Dordrecht, IX + 583 pp.

JAŻDŻEWSKI K., KONOPACKA A. \& GRABOWSKI M. 2005. Native and alien malacostracan Crustacea along the Polish Balic Sea coasts in the 20th century. Oceanological and Hydrobiological Studies 34 (Suppl. 1): 175-193.

KONOPACKA A. 1998. Nowy dla Polski gatunek kiełża Dikerogammarus haemobaphes (Eichwald, 1841) (Crustacea, Amphipoda) oraz dwa inne rzadkie gatunki skorupiaków obunogich w Wiśle. Przegląd Zoologiczny 42: 211-218.

KONOPACKA A. 2004. Inwazyjne skorupiaki obunogie (Crustacea, Amphipoda) w wodach Polski. Przegląd Zoologiczny $48: 141-162$.

MicherdzINsKi W. 1959. Kiełże rodzaju Gammarus Fabricius (Amphipoda) w wodach Polski. Acta Zoologica Cracoviensia 4: 527-637.

RUDOLPH K. 1997. Zum Vorkommen des Amphipoden Pontogammarus robustoides Sars, 1894 im Peenemündungsgebiet. Natur und Museum 127: 306-312.

SCHELLENBERG A. 1934. Der Gammarus des deutschen Süsswassers. Zoologischer Anzeiger 108: $209-217$.

STAROBOGATOV J. I. 1995. Vysshije raki: Obshchaja chast'; Amphipoda, Decapoda, Isopoda. In: TSALOLIKHIN S. J. \& ALEKSEEV V. R. (eds.), Opredelitel' presnovodnykh bespozvonochnykh Rossii i sopredel'nykh teritorij, 2: 157 206. Sankt-Petersburg, $632 \mathrm{pp}$.

STRAYER D. E., EVINER V. T., JESChKe J. M. \& PACE M. L. 2007. Understanding the long-term effects of species invasions. Trends in Ecology and Evolution, 21, 11: 645-651.

WILLER A. 1928. Neue Fundorte seltener Crustaceen in Ostpreussen. Schriften der Physikalisch-Ökonomischen Gesellschaft zu Königsberg, 65: 112. 


\section{STRESZCZENIE}

[Inwazja następnego ponto-kaspijskiego gatunku Pontogammarus robustoides (Crustacea, Amphipoda) w Wielkich Jeziorach Mazurskich w pólnocno-wschodniej Polsce]

W kilku stanowiskach w jeziorach Tałty i Bełdany (Wielkie Jeziora Mazurskie) latem 2007 roku stwierdzono występowanie nowego dla tego rejonu gatunku kielża - ponto-kaspijskiego Pontogammarus robustoides. W zgrupowaniu kielży plytkiego litoralu $P$. robustoides byl zdecydowanym dominantem, współwystępując z rodzimym Gammarus lacustris lub z również obcym, niedawno zarejestrowanym w tym akwenie (Jażdżewski 2003) Dikerogammarus haemobaphes. Przedyskutowano różne możliwości dotarcia $P$. robustoides do Wielkich Jezior Mazurskich.

Accepted: 28 March 2008 